\title{
Cementation of Bioproducts Generated from Biodegradation of Radioactive Cellulosic-Based Waste Simulates by Mushroom
}

\author{
S. B. Eskander, ${ }^{1}$ S. M. Abd El-Aziz, ${ }^{1}$ H. El-Sayaad, ${ }^{2}$ and H. M. Saleh ${ }^{1}$ \\ ${ }^{1}$ Radioisotope Department, Nuclear Research Center, Atomic Energy Authority, Dokki, Giza 12311, Egypt \\ ${ }^{2}$ Middle Eastern Regional Radioisotope Centre for the Arab Countries, Dokki, Giza 12311, Egypt \\ Correspondence should be addressed to H. M. Saleh, hosamsaleh70@yahoo.com
}

Received 12 October 2012; Accepted 29 October 2012

Academic Editors: M.-H. Li and P. Mäki-Arvela

Copyright $(2012$ S. B. Eskander et al. This is an open access article distributed under the Creative Commons Attribution License, which permits unrestricted use, distribution, and reproduction in any medium, provided the original work is properly cited.

\begin{abstract}
The current work was devoted to study the solidification of bioproducts originated from the bioremediation of mixture of solid cellulose-based radioactive waste simulates using a mushroom (Pleurotus pulmonarius), in Portland cement. The obtained solidified waste form was subjected to mechanical integrity qualification after curing periods of 28 and 90 days. Chemical performance of the cement-waste form was also evaluated in different leachant media during 540 days. The results obtained gave useful information about the mechanical, physical, and chemical performances of the final cement-waste form incorporated the radioactive bioproducts. Moreover, it indicated that cement can provide a highly durable form that ensures a long-term stability of the solidified waste material and can act as a first barrier against the release of radiocontaminants from radioactive wastes to the surrounding environment.
\end{abstract}

\section{Introduction}

The worldwide problem of the radioactive wastes generated from peaceful applications of radioisotopes is of a paramount importance for the future exploitation of the advantages of nuclear technology in both energy- and non-energy-related fields.

Bioremediation of solid cellulose-based radioactive waste is a new process based on the capability of living organisms to biodegrade, to bioabsorb, to bioconcentrate, and to biostabilize the radionuclides from the contaminated waste accompanyied with a concurrent reduction in its volume. Research work based on this process was started in our laboratory since more than ten years and was applied for treatment of some liquid and solid radioactive waste simulates [1-3].

Solid cellulose-based radioactive waste simulates (e.g., mixture of contaminated protective clothes, ruined cotton, and exhausted tissue and filter paper) have been remediated using a mushroom. The remaining bioproducts including the growing mushroom and the undegraded part of the compost have been immobilized in Portland cement (PC). The obtained solidified waste form is supposed to be finally disposed off or safely stored in a specific repository isolated from humans and their environment for long periods [4]. Although cement, as a solidifying matrix, has several disadvantages, that is, low volume reduction and relatively high leachability, yet it possesses many practical advantages, such as good mechanical integrity, low cost, and ease of operation in addition to radiation and thermal stabilities [5].

Preliminary experiments were performed to investigate the suitability of PC for waste fixation during encapsulation of bioproducts resulted from the bioremediation of cellulosebased waste simulates. Cement-waste forms with different mixing ratios of cement paste to the bioproducts were prepared. Their compressive strengths were measured to evaluate the mechanical integrity. Leaching test was carried out for the cement-waste forms for more than 500 days of immersion according to the method recommended by the International Atomic Energy Agency [6]. The incremental 
TABLE 1: Elemental analyses of bioproduct components before and after biodegradation.

\begin{tabular}{lccc}
\hline Components & Nitrogen, \% & Carbon, \% & Hydrogen, \% \\
\hline Mushroom & 5.77 & 41.63 & 6.57 \\
Compost remained & 0.35 & 42.1 & 6.81 \\
\hline
\end{tabular}

TABle 2: The chemical compositions of Portland cement in percent.

\begin{tabular}{cccccccc}
\hline $\mathrm{SiO}_{2}$ & $\mathrm{Al}_{2} \mathrm{O}_{3}$ & $\mathrm{Fe}_{2} \mathrm{O}_{3}$ & $\mathrm{CaO}$ & $\mathrm{MgO}$ & $\mathrm{K}_{2} \mathrm{O}$ & $\mathrm{SO}_{3}$ & Insoluble residues \\
\hline 19.84 & 4.74 & 4.0 & 61.01 & 2.5 & 0.6 & 2.4 & 0.95
\end{tabular}

leach rate $\left(R_{n}\right)$, the diffusion coefficient $\left(D_{e}\right)$, and the leach index $\left(L_{x}\right)$ of both ${ }^{137} \mathrm{Cs}$ and ${ }^{60} \mathrm{Co}$ released from the cemented waste form during the leach test were calculated.

\section{Experimental Work}

2.1. Materials. Bioproducts generated from the biodegradation action of mushroom (Pleurotus pulmonarius) that remediate mixture of cellulose-based wastes (equal ratios of protective clothes, cotton, and paper) were immobilized by cement. The elemental analyses of the cellulose-based mixture as well as that of the mushroom fruiting bodies obtained are represented in Table 1.

The cement used for immobilization of bioproducts was the local Portland cement manufactured according to the Egyptian Standard Specification, ES 4756-1/2005 [7]. The composition of the cement used is shown in Table 2.

Radioactive contaminated composts were subjected to the biodegradation process, and the obtained spiked bioproducts were immobilized in cement matrix and the specimens reached were exposed to chemical tests. Both cesium-137 $\left({ }^{137} \mathrm{Cs}, t_{1 / 2}=30\right.$ years $)$ and cobalt-60 $\left({ }^{60} \mathrm{Co}\right.$, $t_{1 / 2}=5.27$ years) were used contaminants for the substrate before cultivating the mushroom. The two gamma emitter radionuclides $\left({ }^{137} \mathrm{Cs}\right.$ and $\left.{ }^{60} \mathrm{Co}\right)$ were purchased from Amersham, England. In this work, three different leachant media, tap water, groundwater, and seawater, were used to evaluate the capability of the cement-waste form to withstand the repository conditions. The concentration of some ions of interest in these different media is represented in Table 3.

2.2. Methodology. The bioproduct generated from the bioprocessing of a mixture of solid cellulose-based waste simulate using a mushroom was air-dried then in an oven at about $50^{\circ} \mathrm{C}$ until stabilizing its weight. These bioproducts were ground in metallic grinder before immobilization in the cement matrix. Five ratios of the bioproducts relative to cement paste were prepared (i.e., from 1 to $5 \%$ by weight). The cement paste was obtained by mixing the cement powder with water at a water/cement ratio $(\mathrm{w} / \mathrm{c})$ equal to 0.35 . It is worth mentioning that before mixing the bioproducts with the cement paste, it should be saturated with water, firstly. The whole cement-waste blend was compacted by hand for the predetermined period and poured into cylindrical molds. These molds were covered with polyethylene cover and cured to harden at room temperature $\left(25 \pm 5^{\circ} \mathrm{C}\right)$ under their humid conditions. Thereupon solid blocks were demolded after 28 or 90 days before subjecting them to a mechanical test. Compressive strength of 3-5 cement-waste specimens ( $60 \pm 2 \mathrm{~mm}$ height and $31 \pm 0.5 \mathrm{~mm}$ diameter $)$ was determined using Ma test, E-159 sp apparatus.

To evaluate the chemical characterization, spiked solid cement-waste form blocks were prepared by mixing $2 \%$ by weight of the bioproducts with cement paste of w/c ratio of 0.35 . After 28 days of curing, the contaminated blocks with either ${ }^{137} \mathrm{Cs},{ }^{60} \mathrm{Co}$, or both were hang up in plastic jars ensuring that the sample was surrounded by at least $10 \mathrm{~mm}$ of leachant on each direction. Each jar was filled with one of the three immersion media, namely, tap water, groundwater, or seawater, then the contact was allowed for time intervals following the method recommended by IAEA [8].

Radionuclides' incremental leach rate $\left(R_{n}\right)$, diffusion coefficient $\left(D_{e}\right)$, and leach index $\left(L_{x}\right)$ were calculated for the cement-waste forms at various leaching times by counting the radioactivity in various leachant media using $3 \times 3$ inch NaI well-type crystal, Multichannel analyzer, PCAP program (USA).

To follow the immobilized bioproducts originated from the bioremediation step, after the setting and curing periods, IR analysis was carried for bioproduct, plain cement, and cement-waste form. IR spectra were carried out using (Perkin-Elmer spectrum RX IFTIR system). The specimens were prepared by mixing $1 \mathrm{mg}$ of the sample as powder with $200 \mathrm{mg}$ of $\mathrm{KBr}$ (AR grade). Spectral analysis was performed in the range of $4000-400 \mathrm{~cm}^{-1}$ with spectral resolution of $1 \mathrm{~cm}^{-1}$.

\section{Results and Discussion}

Portland cement was favored as an immobilizing matrix according to its numerous advantages such as working simplicity, low cost, and acceptable mechanical and thermal stability. The long-term safety of radioactive waste disposal facilities is usually demonstrated by the support of a safety assessment [9]. One of the issues determining the safety of the whole radioactive waste management scheme is the mechanical, chemical, physical, and so forth requirements that were fulfilled by the waste forms.

Figure 1 describes the effect of incorporating various ratios the bioproduct into the cement matrix on the mechanical integrity of the final cement-waste form cured for two periods. It was found that increasing of the bioproduct content is accompanied with apparent deterioration in the compressive value of the cement-waste form.

This may be attributed to the heterogeneity of the final product resulting from mixing the bioproduct with cement. However, it is worth mentioning that the values of compressive strength obtained for the cement-waste form immobilizing up to $5 \%$ dry bioproducts, either after curing of 28 days or after 90 days, are still higher than that recommended by the Nuclear Commission Regulatory (NRC) [10]. Aging the cement-waste form immobilizing different ratios of the bioproduct for 90 days before the compression test was associated with relative improvement 
TABLE 3: Some ions of interest present in tap water, groundwater, and seawater.

\begin{tabular}{lccccccc}
\hline \multirow{2}{*}{ Leachant } & $\mathrm{pH}$ & $\mathrm{K}^{+}$ & \multicolumn{3}{c}{ Soluble cations (ppm) } & \multicolumn{3}{c}{ Soluble anions (ppm) } \\
& & $\mathrm{Na}^{+}$ & $\mathrm{Mg}^{2+}$ & $\mathrm{Ca}^{2+}$ & $\mathrm{Cl}^{-}$ & $\mathrm{SO}_{4}{ }^{2-}$ & $\mathrm{HCO}_{3}{ }^{-}$ \\
\hline Tap water & 6.90 & 0.08 & 1.07 & 1.2 & 1.4 & 0.77 & 0.7 \\
Groundwater & 7.20 & 23 & 149 & 13 & 74 & 137 & 317 \\
Seawater & 7.93 & 8.4 & 652.6 & 96.9 & 28.06 & 496.9 & 60.8 \\
\hline
\end{tabular}

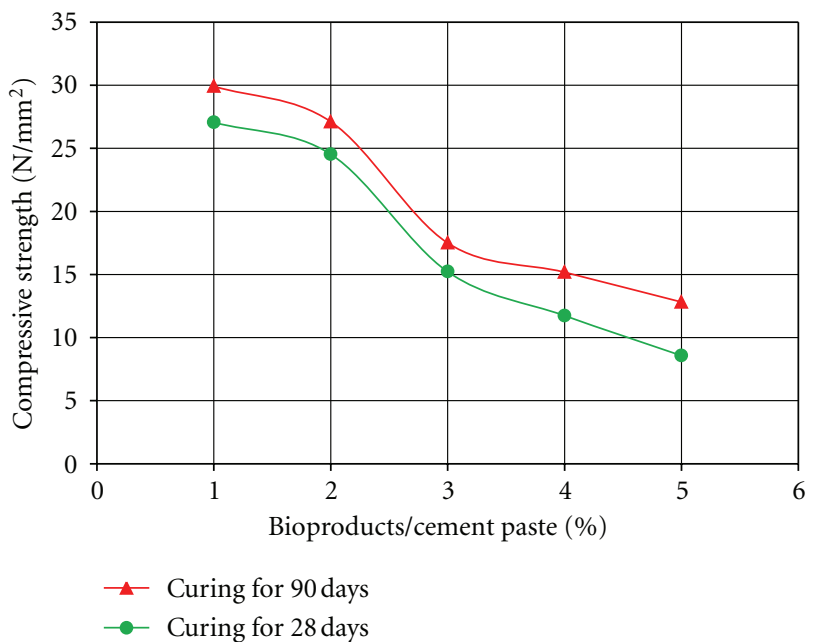

FIgURE 1: Mechanical integrity of cement-waste form containing various ratios of bioproduct and cured for different periods.

in their mechanical integrity compared to that aged for 28 days, which could be explained by formation of carbonate.

Carbonation reaction can be formed within the cementwaste form when the atmospheric carbon dioxide reacts with cementitious materials resulting in the formation of calcium carbonate. The major reactions of cement with $\mathrm{CO}_{2}$ could be simplified as follows,

$$
\begin{gathered}
\mathrm{Ca}(\mathrm{OH})_{2(\mathrm{~s})}+\mathrm{CO}_{2(\mathrm{~g})} \longrightarrow \mathrm{CaCO}_{3(\mathrm{~s})}+\mathrm{H}_{2} \mathrm{O}_{(\mathrm{l})} \\
\mathrm{CSH}_{(\mathrm{s})}+\mathrm{CO}_{2(\mathrm{~g})} \longrightarrow \mathrm{CaCO}_{3(\mathrm{~s})}+\mathrm{SiO}_{2} \cdot \mathrm{nH}_{2} \mathrm{O}_{(\mathrm{s})}+\mathrm{H}_{2} \mathrm{O}_{(\mathrm{l})}
\end{gathered}
$$

All the calcium containing phases existent in the cement are subjected to carbonation, with $\mathrm{Ca}(\mathrm{OH})_{2}$ being the more rapidly reactive compound. These reactions lead to the formation of calcium carbonate, silica gel, and metallic oxides, which eventually come accumulated causing the obstruction of the pores which in turn increases the mechanical integrity of the final waste form [11]. Based on the data obtained from the mechanical integrity measurements, it could be stated that the final cemented waste form containing up to $5 \%$ by its weight of the bioproduct comes from the bioremediation of cellulose-based waste simulates can fulfill the requirements needed for safe handling, transportation, interim storage, and final subsequent disposal process.

IR studies were conducted to identify the effect of mixing the bioproduct with cementitious materials. The infrared spectra of the bioproduct, plain cement, and cement-waste form (containing $2 \%$ by weight bioproduct) after 28 days of curing at room temperature are shown in Figure 2.

In a plain cement spectrum, the absorption band near $3600 \mathrm{~cm}^{-1}$ characteristic of portlandite $\left(\mathrm{Ca}(\mathrm{OH})_{2}\right)$ was observed (Figure 2(b)). This band was also clearly visible with cement-waste form (Figure 2(c)). Combined and absorbed water of the cementitious components were identified near to $3440 \mathrm{~cm}^{-1}$ while a band of molecular water was distinguished near $1640 \mathrm{~cm}^{-1}$. Bands near 1420,870 , and $710 \mathrm{~cm}^{-1}$ may be attributed to the presence of carbonate phase while the shoulder near $1116 \mathrm{~cm}^{-1}$ is related to the sulphate phase. On the other hand, band near $920 \mathrm{~cm}^{-1}$ may refer to anhydrous calcium silicate (Figure 2(b)) [12, 13]. It should be stated that an identical spectrogram is identified in the cement-waste form (Figure 2(c)). However, it is worth mentioning that the bands characterizing the bioproduct, as cellulosic materials, Figure 2(a), can be listed as following, the strong band at $1630 \mathrm{~cm}^{-1}$ was due to stretching vibration of the aldehyde carbonyl group $-\mathrm{C}=\mathrm{O}$ in the poly saccharide structure, band near $1370 \mathrm{~cm}^{-1}$ was referring to $\mathrm{C}-\mathrm{CHO}$ stretching frequency in the $\mathrm{O}=\mathrm{C}-\mathrm{O}$ group, and band close to $1035 \mathrm{~cm}^{-1}$ connected to asymmetric vibration in the C$\mathrm{O}-\mathrm{C}$ etheric bridge. Glucose ring stretching mode in the cellulose polymer appeared near $890 \mathrm{~cm}^{-1}$ (Figure 2(a)) [14]. These bands were hardly manifested in the spectrum of the cement-waste form. This confirmed that immobilizing of the bioproduct coming from the biodegradation process of cellulose-based waste mixture did not affect the curing and hardening scheme of the cementitious materials. Consequently, it could be stated that cement was a suitable material for immobilizing this category of wastes.

The following mathematical treatment can describe the chemical performance behavior of the final cemented waste form. These extrapolations are deduced according to the IAEA review [8] and the suggested diffusional model for the leachability of contaminants from the final waste form.

The quantity of radionuclides leached out from a unit surface area during a definite leaching period can be calculated as follows:

$$
a_{n}=2 A_{0} \sqrt{D_{e} \frac{t_{n}}{\pi}}
$$

where $A_{0}$ is initial sample activity at time zero $(\mathrm{Bq}) ; a_{n}$ is activity leached out of sample after leaching time $t ;(\mathrm{Bq}) ; t_{n}$ is duration of leaching renewal period, (days); $D_{e}$ is effective diffusion coefficient, $\left(\mathrm{cm}^{2} /\right.$ day $)$. 


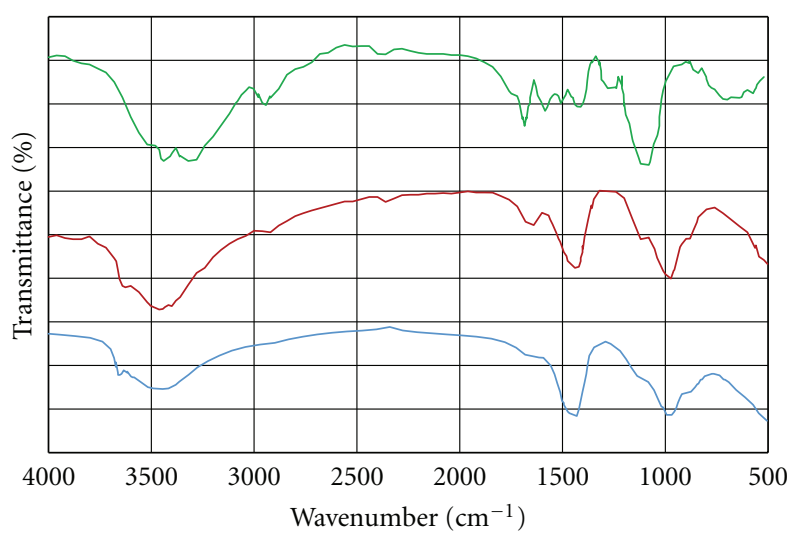

(a) Bioproducts

(b) Plain cement

(c) Cement $+2 \%$ bioproducts

FIGURE 2: IR spectra of bioproduct, plain cement, and cement-waste form.

Basing on the previous relation, the incremental leach rate could be driven as

$$
\begin{aligned}
& \frac{\sum a_{n}}{A_{0}}=2\left(\frac{S}{V}\right) \cdot \sqrt{D_{e} \frac{\sum t_{n}}{\pi}}, \\
& \frac{\sum a_{n}}{A_{0}} \cdot\left(\frac{V}{S}\right)=2 \sqrt{D_{e} \frac{\sum t_{n}}{\pi}},
\end{aligned}
$$

where $S$ is sample surface $\left(\mathrm{cm}^{2}\right) ; V$ is sample volume $\left(\mathrm{cm}^{3}\right)$.

A plot describing the $\sum a_{n} / A_{0}$ versus $\sum t_{n}$ could be used to calculate the effective diffusion coefficient $\left(D_{e}\right)$ :

$$
D_{e}=\left(m^{2} \pi / 4\right)\left(V^{2} / S^{2}\right),
$$

where $m$ is the slope of the straight line.

In addition, the leach index $\left(L_{x}\right)$, as a merit figure for the waste form, could be obtained according to

$$
L_{x}=\log \left(\frac{1}{D_{e}}\right)
$$

Moreover, the chemical performance was expressed by computing the incremental leach rate $\left(R_{n}\right)(\mathrm{cm} / \mathrm{d})$ based on the following relation [5]:

$$
R_{n}=\frac{\sum a_{n}}{A_{0}} \frac{V}{S} \frac{1}{\sum t_{n}}(\mathrm{~cm} / \mathrm{d})
$$

Cemented waste blocks containing $2 \%$ by their weight contaminated bioproduct have been let to set and cure for 28 days, after that time, it was hang separately in three leachant media at room temperature $\left(25 \pm 5^{\circ} \mathrm{C}\right)$. Either ${ }^{137} \mathrm{Cs}$ or ${ }^{60} \mathrm{Co}$ was counted in the immersion media every day up to the first month from starting the test, then each week for the second month, then monthly for the following 180 days, and then each six months for more than 500 days.

All the obtained leaching curves exhibited identical behavior: an enhancement of high $R_{n}$ during the initial period, which was recorded for 25 days or near, followed by a
Table 4: Diffusion coefficient $\left(D_{e}\right)\left(\mathrm{cm}^{2} / \mathrm{d}\right)$ of cement waste forms containing various radionuclides in different leachants after 540 days of immersion.

\begin{tabular}{lccc}
\hline \multirow{2}{*}{ Leachant type } & \multicolumn{3}{c}{ Diffusion coefficient $D_{e},\left(\mathrm{~cm}^{2} / \mathrm{d}\right)$} \\
& ${ }^{60} \mathrm{Co}$ & ${ }^{137} \mathrm{Cs}$ & ${ }^{60} \mathrm{Co}+{ }^{137} \mathrm{Cs}$ \\
\hline Tap water & $2.6 E-11$ & $3.2 E-10$ & $5.1 E-11$ \\
Groundwater & $1.6 E-10$ & $1.5 E-9$ & $7.1 E-10$ \\
Seawater & $4.3 E-11$ & $3.1 E-10$ & $1.4 E-10$ \\
\hline
\end{tabular}

TABLE 5: Leach index $\left(L_{x}\right)$ of cement waste form containing various radionuclides in different leachants after 540 days.

\begin{tabular}{lccc}
\hline Leachant type & \multicolumn{3}{c}{ Leach index $\left(L_{x}\right)$} \\
& ${ }^{60} \mathrm{Co}$ & ${ }^{137} \mathrm{Cs}$ & ${ }^{60} \mathrm{Co}+{ }^{137} \mathrm{Cs}$ \\
\hline Tap water & 10.5 & 9.6 & 10.3 \\
Groundwater & 9.15 & 8.8 & 8.82 \\
Seawater & 10.5 & 9.36 & 9.85 \\
\hline
\end{tabular}

significant reduction in the rate which is broadly maintained up to long periods of leaching. The high leachability of the cement-waste form of the first period under different experimental conditions can be explained by what is well known as a surface washing-off process. During this stage, equilibrium was obtained between the surface pores of the cement waste form and the ions of the leachant media. On the other hand, the second part of the leaching curve was controlled by the diffusion process accompanied with very slow leach rates (Figures 3 and 4).

Slight differences in $R_{n}$ of ${ }^{137} \mathrm{Cs}$ or ${ }^{60} \mathrm{Co}$ from the cementwaste form in various leachants are observed in Figures 3 and 4, respectively. However, it should be noted that the leachability of both radionuclides in tap water was lower than that in groundwater or seawater. This may be attributed to the rapid equilibrium established between pore's solution in the cement surface and the ions in the leachant solution, bearing in mind the high salt content in both groundwater and seawater relative to that in tap water Table 3 .

Diffusion coefficient, $D_{e},\left(\mathrm{~cm}^{2} / \mathrm{d}\right)$ of the cement-waste form, was decreased in the order of ${ }^{137} \mathrm{Cs}>{ }^{137} \mathrm{Cs}+{ }^{60} \mathrm{Co}>>^{60}$ Co in all leachants (Table 4).

Cesium is alkaline element and highly soluble radionuclide within the basic environment of cement. On the other hand, cobalt may form insoluble hydroxide at this higher $\mathrm{pH}$ condition. Therefore, the leachability of ${ }^{137} \mathrm{Cs}$ to the extract was greater than that of ${ }^{60} \mathrm{Co}$ from the cement-waste form immersed in the same medium. This can also explain the higher diffusivity of the final waste form immobilizing the bioproduct contaminated with both radionuclides compared to that including bioproduct spiked with ${ }^{60} \mathrm{Co}$ only, (Table 4). This trend was in agreement with studies previously published $[15,16]$.

The data represented in Table 5 indicated clearly that the leach indices for either ${ }^{137} \mathrm{Cs}$ or ${ }^{60} \mathrm{Co}$ or both together in various leachants were usually greater than six, the figure which is recommended as a limit for immobilizing matrix to be acceptable for subsequent disposal process [17]. 


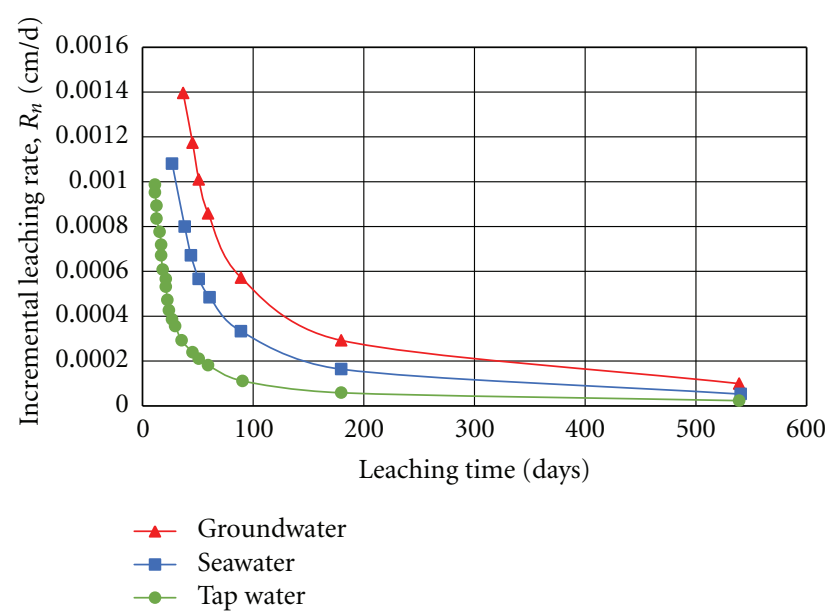

FIGURE 3: Incremental leaching rate $\left(R_{n}\right)$ versus leaching time for ${ }^{137} \mathrm{Cs}$ in different leachants.

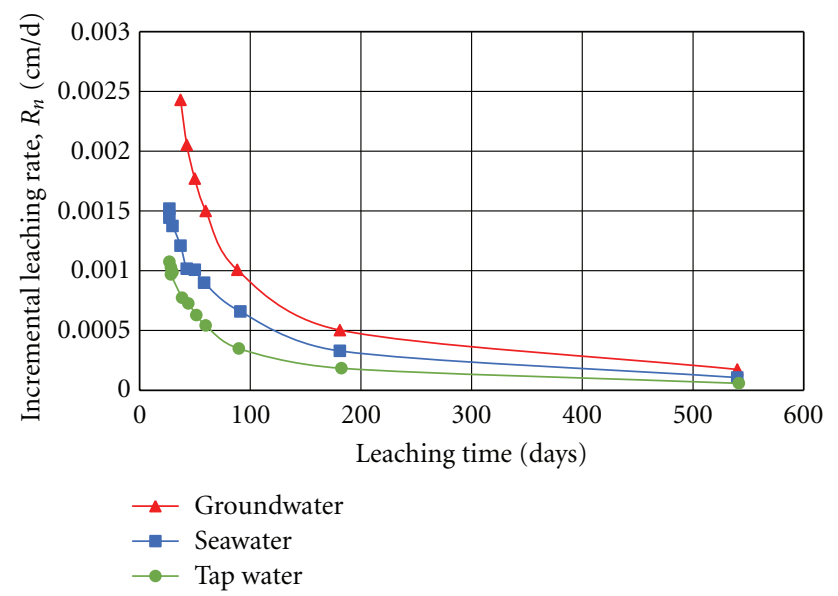

FIGURE 4: Incremental leaching rate $\left(R_{n}\right)$ versus leaching time for ${ }^{60} \mathrm{Co}$ in different leachants.

The relative high $L_{x}$ figures reached may be attributed to the role of mushroom to biostabilize the radionuclides within its all tissues, and hence retarding their release to the various media was observed. A similar explanation was reported previously in the literature [18].

According to all data obtained from the leach test, it could be stated that cement was an acceptable matrix for immobilizing the contaminated bioproducts even in case of the breakthrough of different type water into the disposal site. In addition, the data obtained can give the possibility to extrapolate in the next 20 years and more, keeping in mind the decay of radionuclides used.

\section{Conclusion}

Based on the experimental results obtained from direct encapsulation of solid cellulosic-based waste simulate in cement without any treatment and that for immobilization of the bioproduct generated from the biodegradation process, it could be reported an improvement in physical, mechanical, and chemical characterizations of the final waste form following the second route. Therefore, the whole approach (i.e., bioremediation followed by cementation of the bioproduct) seems to be promising for treatment and solidification of unneglected part of solid lowand intermediate-level radioactive solid wastes (i.e., solid cellulose-based waste).

\section{References}

[1] H. El-Sayaad, Effect of gamma radiation on the growth and metabolism of Pleurotus ostreatus [M.S. thesis], Faculty of Science, Tanta University, Tanta, Egypt, 2002.

[2] H. El-Sayaad, Biological treatment of organic solid and radioactive wastes by mushroom (Pleurotus spp.) [Ph.D. thesis], Faculty of Science, Tanta University, Tanta, Egypt, 2008.

[3] H. A. Kamel, S. B. Eskander, and M. A. S. Aly, "Physiological response of Epipremnum aureum for cobalt-60 and cesium137 translocation and rhizofiltration," International Journal of Phytoremediation, vol. 9, no. 5, pp. 403-417, 2007.

[4] J. Y. Kim, C. H. Chung, H. J. Choi, and C. L. Kim, "A study on leaching characteristics of paraffin waste form including boric acid," Journal of the Korean Nuclear Society, vol. 32, no. 1, pp. $10-16,2000$.

[5] I. Plećaš and S. Dimović, "Curing time effect on the fraction of ${ }^{137} \mathrm{Cs}$ from cement-ion exchange resins-bentonite clay composition," in Proceedings of the International Conference of Nuclear Energy for New Europe, pp. 702. 1-702. 4, Portorož, Slovenia, Septemper 2007.

[6] International Atomic Energy Agency (IAEA), Management of Low and Intermediate Level Radioactive Wastes With Regard to Their Chemical Toxicity, IAEA, 2002.

[7] Egyptian Standard Specifications, ES4756-1, EM1 (42. 5N), Egypt, 2005.

[8] E. D. Hespe, "Leach testing of immobilized radioactive waste solids - a proposal for a standard method," International Atomic Energy Agency, Atomic Energy Review, vol. 9, no. 1, pp. 195-207, 1971.

[9] J. Perko, D. Mallants, E. Vermariën, and W. Cool, "Verification and validation of flow and transport in cracked saturated porous media," in Proceedings of the COMSOL Conference, Hanover, Germany, 2008.

[10] Nuclear Regulatory Commission, N.R.C. Regulation, title 10, section 61-56, 2002.

[11] P. H. R. Borges, N. B. Milestone, J. O. Costa, C. J. Lynsdale, T. H. Panzera, and A. L. Christophoro, "Carbonation durability of blended cement pastes used for waste encapsulation," Materials and Structures, vol. 45, no. 5, pp. 663-678, 2012.

[12] K. Baltakys, R. Jauberthie, R. Siauciunas, and R. Kaminskas, "Influence of modification of $\mathrm{SiO}_{2}$ on the formation of calcium silicate hydrate," Materials Science-Poland, vol. 25, no. 3, pp. 663-670, 2007.

[13] C. E. M. Gomes and O. P. Ferreira, "Analyses of microstructural properties of VA/VeoVA copolymer modified cement pastes," Polymers, vol. 15, no. 3, 2005.

[14] H. M. Saleh, Treatment and solidification of hazardous organic wastes [Ph.D. thesis], Faculty of Science, Cairo University, Cairo, Egypt, 2004.

[15] R. H. Burns, "Solidification of low and intermediate level wastes," Atomic Energy Reviews, vol. 9, no. 3, pp. 547-552, 1971.

[16] I. Plećaš and S. Dimovic, "Curing time effect on compressive strength and incremental leaching rates of ${ }^{137} \mathrm{Cs}$ and ${ }^{60} \mathrm{Co}$ in 
cement immobilized sludge," Progress in Nuclear Energy, vol. 48, no. 7, pp. 629-633, 2006.

[17] Engineering Manual Em-1110-1-4002, US Army Corps. of Engineers Publication Department, pp. 9. 4-9. 5, 1997.

[18] G. Rufyikiri, Y. Thiry, L. Wang, B. Delvaux, and S. Declerck, "Uranium uptake and translocation by the arbuscular mycorrhizal fungus, Glomus intraradices, under root-organ culture conditions," New Phytologist, vol. 156, no. 2, pp. 275-281, 2002. 

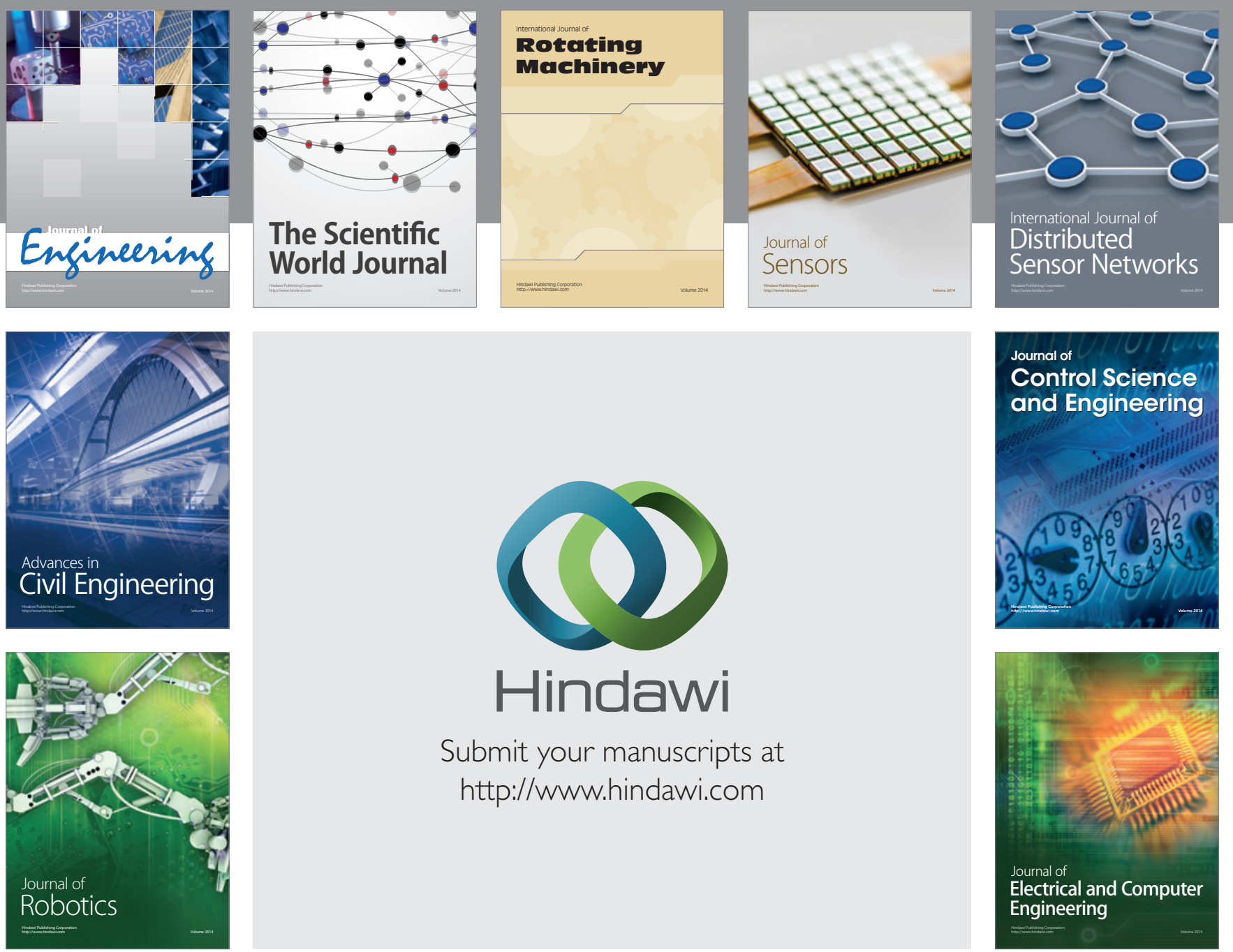

Submit your manuscripts at

http://www.hindawi.com
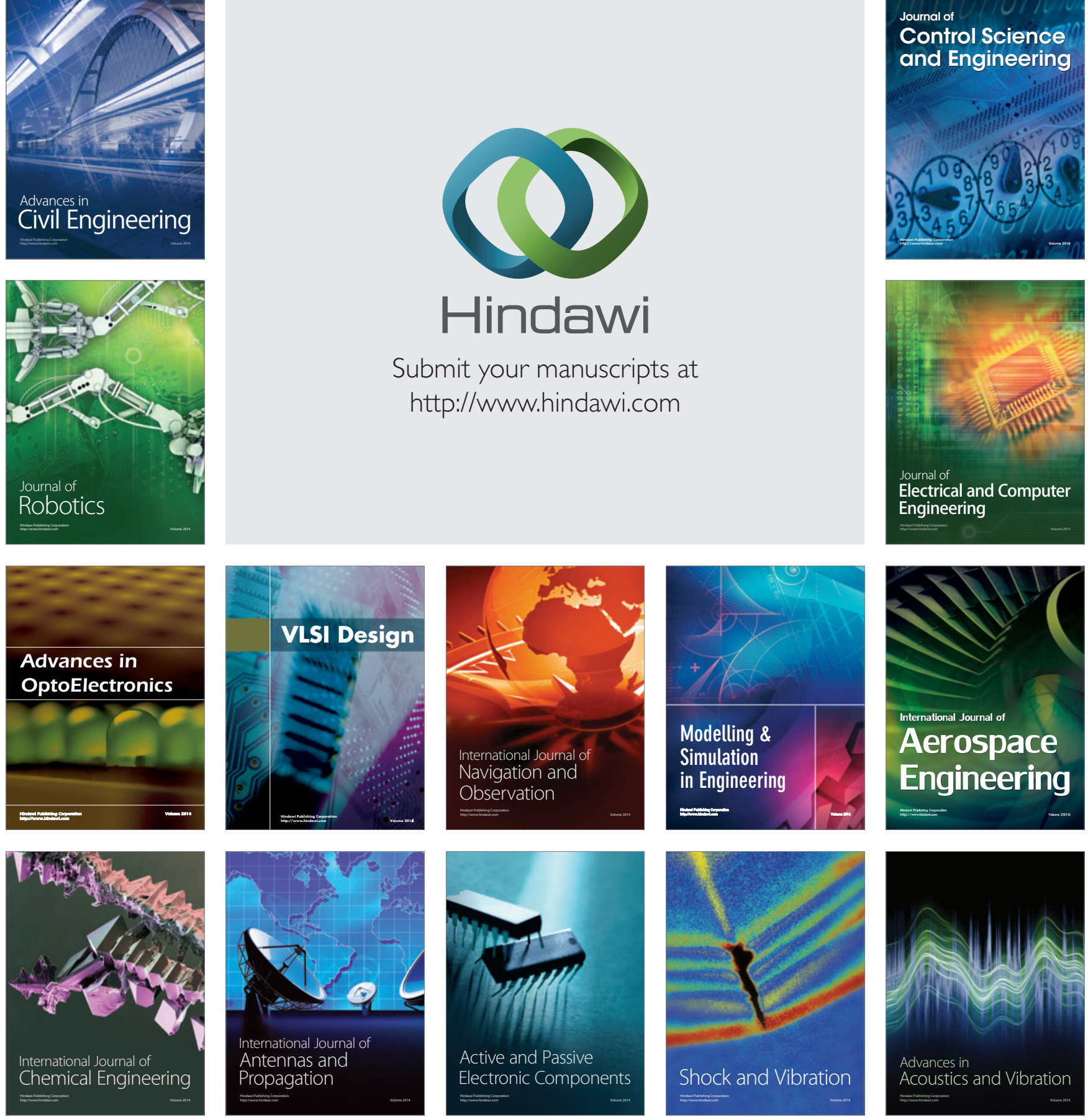